\title{
Mixture compatibility of ChinNPV baculovirus with herbicides and fungicides used in soybean
}

\section{Compatibilidade de mistura do baculovírus ChinNPV com herbicidas e fungicidas utilizados na soja}

\author{
Rodrigo Mendes Antunes Maciel ${ }^{1}$; Junio Tavares Amaro ${ }^{2}$; Fernanda Caroline \\ Colombo ${ }^{3}$; Pedro Manuel Oliveira Janeiro Neves ${ }^{4}$; Adeney de Freitas Bueno ${ }^{5 *}$
}

\section{Highlights}

ChinNPV is compatible in a mixture with tested herbicides.

ChinNPV is compatible in a mixture with tested fungicides used in agriculture.

ChinNPV has insecticide potential with herbicides and fungicides after two hours.

\begin{abstract}
Chrysodeixis includens Walker, 1858 (Lepidoptera: Noctuidae), commonly known as soybean looper, is one of the main pests that reduces soybean yield due to its defoliation capacity. Population outbreaks of this pest can occur in the vegetative stage of the crop, together with the occurrence of weeds or in the reproductive stage, at the same time as that of diseases. This often requires the use of pesticides against pests and weeds, or fungi at the same time. Thus, the objective of this study was to evaluate the compatibility of baculovirus ChinNPV with different synthetic chemical herbicides and fungicides used in soybean. Four bioassays were carried out, with or without the addition of ChinNPV to different herbicides and fungicides. The artificial diets were immersed in the solutions of the pesticides and their mixture and supplied to the caterpillars of $C$. includens, immediately and after one and two hours of mixing. The evaluation was performed by quantifying the number of dead caterpillars. The results showed that the ChinNPV baculovirus is compatible for mixing with all studied herbicides and fungicides, even after two hours of mixing. In all the studied scenarios, baculovirus mixed with chemical pesticides triggered the same mortality as sprayed with baculovirus alone, and values of over $80 \%$ mortality of $C$. includens have always been recorded.
\end{abstract}

Key words: Biological control. Entomopathogen. Integrated pest management. Soybean looper.

1 Graduate PhD Student of the Postgraduate Program in Entomology, Universidade Federal do Paraná, UFPR, Curitiba, PR, Brasil. E-mail: rodrimaciel@hotmail.com

2 Doctor in Agronomy, Universidade Estadual de Londrina, UEL, Londrina, PR, Brasil. E-mail: juniotavares@ibest.com.br;

${ }^{3}$ Graduate PhD Student of the Postgraduate Program in Agronomy, UEL, Londrina, PR, Brasil. E-mail: fer.colombo@ hotmail.com

${ }^{4}$ Prof. Dr. of Postgraduate Program in Agronomy, UEL, Londrina, PR, Brasil. E-mail: pedroneves@uel.br

${ }^{5}$ Researcher of Empresa Brasileira de Pesquisa Agropecuária, EMBRAPA/Soja, Londrina, PR, Brasil. E-mail: adeney. bueno@embrapa.br

* Author for correspondence

Received: July 30, 2020 - Approved: June 09, 2021 


\section{Resumo}

Chrysodeixis includens Walker, 1858 (Lepidoptera: Noctuidae) falsa-medideira é uma das principais pragas que reduz o rendimento da soja devido à sua capacidade de desfolha. Surtos populacionais desta praga podem ocorrer no estágio vegetativo da cultura, juntamente com a ocorrência de ervas daninhas ou no estágio reprodutivo, ao mesmo tempo em que ocorrem doenças. Muitas vezes, isso pode exigir o uso de pesticidas contra pragas e ervas daninhas ou fungos ao mesmo tempo. Assim, o objetivo deste trabalho foi avaliar a compatibilidade do baculovírus ChinNPV com diferentes herbicidas e fungicidas químicos sintéticos utilizados na soja. Foram realizados quatro bioensaios, com ou sem adição de ChinNPV em diferentes herbicidas e fungicidas. As dietas artificiais foram imersas nas soluções dos agrotóxicos e sua mistura e fornecidas às lagartas de $C$. includens, imediatamente e após uma e duas horas de mistura. A avaliação foi realizada quantificando o número de lagartas mortas. Os resultados mostraram que o baculovírus ChinNPV é compatível para mistura com todos os herbicidas e fungicidas estudados mesmo após duas horas de mistura. Em todos os cenários estudados, o baculovírus misturado com pesticidas químicos desencadeou a mesma mortalidade que o baculovírus pulverizado sozinho, e valores de mais de $80 \%$ da mortalidade de $C$. includens sempre foram registrados.

Palavras-chave: Controle biológico. Entomopatógeno. Manejo integrado de pragas. Falsa-medideira.

\section{Introduction}

Soybean, Glycine max [(L.) Merrill], is one of the major worldwide crops and Brazil is one of its largest producers (Bueno, Raetano, Dorneles, \& Carvalho, 2017; Hartman, West, \& Herman, 2011). However, numerous diseases, weeds, and arthropods reduce its yield (Oerke, 2006). The simultaneous incidence of pest organisms causes the overuse of chemicals to control them (Pignati et al., 2017). Among the groups of pest organisms that feed on soy, the defoliating caterpillars of the Noctuidae family are unique for their injury capacity (Bortolotto et al., 2015).

Chrysodeixis includens Walker, 1858 (Lepidoptera: Noctuidae) is a key pest in soybean, against which control is carried out predominantly with synthetic chemical insecticides (Stacke et al., 2020). This caterpillar species often occurs in the same plant developmental stages (Zulin, Ávila, \&
Schlick-Souza, 2018) in which crops are also injured by weeds or plant pathogens (Hartman et al., 2011). Therefore, it is a common practice in the field that pesticides are sprayed simultaneously to manage pests and weeds early in the crop season or to manage pests and diseases late in the crop season. While weed and disease management is exclusively done with the use of chemical herbicides and fungicides, $C$. includens can be alternatively managed by spraying baculovirus with efficacy (Godoy et al., 2019; Moscardi, 1999).

There is an increasing demand worldwide for pest management tools that are less harmful to the environment, which requires the use of more environmentally friendly pest management strategies and fewer synthetic chemicals. One of the most important tools for sustainable pest management is the use of augmentative biological control, among which baculovirus is distinct, particularly for the control of caterpillars, due to its high virulence 
and specificity, causing efficient epizootics in the target insect population (Moscardi, 1999; Muraro et al., 2018). However, to succeed in integrated pest management, it is crucial to harmoniously use different control tools, particularly the use of harmless pesticides with natural biological control agents. Thus, it is of theoretical and practical interest to study the mixture compatibility of ChinNPV with different herbicides and fungicides. Moreover, not only is it important to evaluate the efficacy of pesticides immediately after mixing but also at different times following mixing because in field conditions, it might take a few hours for growers to spray the whole crop after preparing the sprayer with pesticides. Therefore, this study aimed at verifying the mixture compatibility of ChinNPV with herbicides and fungicides commonly used in soybean crops with immediate application or one or two hours after mixing.

\section{Material and Methods}

Four independent bioassays were carried out evaluating $C$. includens mortality: pesticides (fungicides and herbicides) (bioassay 1), ChinNPV mixture with herbicides and fungicides immediately (bioassay 2), after one hour (bioassay 3), and after two hours (bioassay 4) (Table 1). The bioassays were carried out under controlled conditions of temperature $\left(25 \pm 2^{\circ} \mathrm{C}\right)$, relative humidity $(70 \pm$ $10 \%)$, and photoperiod (14:10 h light/dark) at the Laboratory of Entomology from Embrapa Soja, Londrina, Paraná, Brazil.

\section{Laboratory rearing of $\mathrm{C}$. includens}

Chrysodeixis includens caterpillars that were used in the bioassays originated from insects reared at Embrapa Soybean (one of the units of the Brazilian Agricultural Research Corporation), Londrina, State of Paraná, Brazil. The insects were kept under controlled environmental conditions inside Biochemical Oxygen Demand (BOD) climate chambers (ELETROLab ${ }^{\circledR}$, model EL 212, São Paulo, SP, Brazil) set at $70 \pm 10 \%$ humidity, temperature of $25 \pm 2^{\circ} \mathrm{C}$, and a 14:10 h (L:D) photoperiod according to methodologies previously described in literature (Andrade et al., 2016) and briefly summarized as follows.

Chrysodeixis includens individuals were originally collected from soybean fields in Embrapa Soybean Experimental Farm, Londrina, State of Paraná, Brazil (23 11' 11.7" $S$ and $51^{\circ} 10^{\prime} 46.1^{\prime \prime} \mathrm{W}$ ). These populations were kept in the laboratory for approximately 3 years and new field insects were introduced each year to maintain colony quality.

Caterpillars were individually kept in 50-mL plastic cups sealed with cardboard caps, containing an artificial diet developed by Greene, Leppla and Dickerson (1976). Adults were placed in cages (PVC tubes of $10 \mathrm{~cm}$ diameter $\times 21.5 \mathrm{~cm}$ height) and fed with solution ( $10 \mathrm{~g}$ of honey, $60 \mathrm{~g}$ of sugar, $1 \mathrm{~g}$ of sorbic acid, $1 \mathrm{~g}$ of methylparaben / 1 liter of distilled water) and $1 \mathrm{~mL}$ of beer. Cage walls were covered with A4 paper for moth oviposition. Eggs were removed, and the cages were cleaned daily. Eggs were placed into $200-\mathrm{mL}$ plastic cups containing $20 \mathrm{~mL}$ of artificial diet (Greene et al., 1976). The caterpillars were kept in these containers until they reached the 3rd instar when they were used for the trials. 
Mortality of $C$. includens due to the application of different pesticides alone or in combination with ChinNPV

Different suspensions containing herbicides and fungicides (Table 1) used alone or in association with the entomopathogenic baculovirus ChinNPV (Baculovirus Simbiose $\mathrm{WP}^{\circledR} 50 \mathrm{~g} .150 \mathrm{~L} \mathrm{H}^{-1} \mathrm{O}^{-1}$ ) were evaluated in the dosage recommended by the manufacturers. Sterile distilled water and sterile distilled water containing ChinNPV were used as control treatments. The artificial diet (Greene et al., 1976) was cut into cubes $\left(1 \mathrm{~cm}^{3}\right)$ and immersed in the treatments for $5 \mathrm{~s}$, and then placed in plastic containers with a volume of $50 \mathrm{~mL}$, containing two caterpillars of the 3 rd instar. The cubes of diet with the treatments were offered to the caterpillars for $24 \mathrm{~h}$, guaranteeing the consumption of the treatments and later exchanged for cubes of a diet free of any pesticides (Morgado et al., 2020).

Each bioassay was conducted in a completely randomized design with four repetitions, which consisted of a set of 20 caterpillars (10 plastic pots with two caterpillars each). A total of 80 caterpillars were subjected to each suspension. The evaluation was performed daily for ten days to quantify the number of dead caterpillars. The specimen was considered dead when it was immobile and insensitive to mechanical touch using forceps and was considered alive when the specimen was moving and feeding.

\section{Table 1}

Herbicides and fungicides used alone or in a mixture with ChinNPV (Baculovirus Simbiose WP ${ }^{\circledR} 50$ g.150 $\mathrm{L} \mathrm{H}_{2} \mathrm{O}^{-1}$ ) under controlled laboratory conditions (temperature of $25 \pm 2^{\circ} \mathrm{C}$, relative humidity of $70 \pm 10 \%$, and photoperiod of 14:10 $\mathrm{h}$ light/dark) and commercial dose

\begin{tabular}{|c|c|c|c|c|c|}
\hline Pesticide & $\begin{array}{l}\text { Active ingredient } \\
\text { (a.i.) }\end{array}$ & $\begin{array}{l}\text { Commercial } \\
\text { product (c.p.) }\end{array}$ & Chemical group & $\begin{array}{l}\text { Concentration } \\
\text { of a.i. }\end{array}$ & $\begin{array}{l}\text { Dosage } \\
\text { (ha) c. p. }\end{array}$ \\
\hline \multirow{8}{*}{ Herbicide } & Cletodim & Poquer EC ${ }^{\circledR}$ & Oximacyclohexanedione & $240 \mathrm{~g} \mathrm{~L}^{-1}$ & $\begin{array}{c}0.45 \mathrm{~L} .200 \\
\mathrm{~L} \mathrm{H}_{2} \mathrm{O}^{-1}\end{array}$ \\
\hline & $\begin{array}{c}\text { Chlorimurom- } \\
\text { ethyl }\end{array}$ & $\begin{array}{l}\text { Clorimuron } \\
\text { Master Nortox } \\
\text { WG® }\end{array}$ & Sulfonylurea & $250 \mathrm{~g} \mathrm{~kg}^{-1}$ & $\begin{array}{l}80 \mathrm{~g} .200 \\
\mathrm{LH}_{2} \mathrm{O}^{-1}\end{array}$ \\
\hline & Flumioxazin & $\begin{array}{c}\text { Flumyzin } 500 \\
\text { WP }^{\circledR}\end{array}$ & Cyclohexenodicarboximide & $500 \mathrm{~g} \mathrm{~kg}^{-1}$ & $\begin{array}{c}200 \mathrm{~g} .200 \\
\mathrm{~L} \mathrm{H}_{2} \mathrm{O}^{-1}\end{array}$ \\
\hline & $\begin{array}{l}\text { Imazapique + } \\
\text { imazapir }\end{array}$ & $\begin{array}{c}\text { Soyvance Pre } \\
\text { WG }^{\circledR}\end{array}$ & $\begin{array}{l}\text { Imidazolinone + } \\
\text { imidazolinone }\end{array}$ & $\begin{array}{c}525 \mathrm{~g} \mathrm{~kg}^{-1}+ \\
175 \mathrm{~g} \mathrm{~kg}^{-1}\end{array}$ & $\begin{array}{c}100 \mathrm{~g}^{2} 200 \\
\mathrm{~L} \mathrm{H}_{2} \mathrm{O}^{-1}\end{array}$ \\
\hline & $\underset{\text { imazapir }}{\text { Imazapique }}+$ & $\begin{array}{l}\text { Soyvance } \\
\text { WG }{ }^{\circledR}\end{array}$ & $\begin{array}{l}\text { Imidazolinone + } \\
\text { imidazolinone }\end{array}$ & $\begin{array}{c}175 \mathrm{~g} \mathrm{~kg}^{-1}+ \\
525 \mathrm{~g} \mathrm{~kg}^{-1}\end{array}$ & $\begin{array}{c}100 \mathrm{~g} .200 \\
\mathrm{~L} \mathrm{H}_{2} \mathrm{O}^{-1}\end{array}$ \\
\hline & Bentazona & $\begin{array}{c}\text { Basagran } 600 \\
\text { SL }^{\circledR}\end{array}$ & Benzothiadiazinone & $600 \mathrm{~g} \mathrm{~L}^{-1}$ & $\begin{array}{l}1.6 \mathrm{~L} .200 \\
\mathrm{~L} \mathrm{H}_{2} \mathrm{O}^{-1}\end{array}$ \\
\hline & Cletodim & $\begin{array}{c}\text { Select } 240 \\
\text { EC }^{\circledR}\end{array}$ & Oximacyclohexanedione & $240 \mathrm{~g} \mathrm{~L}^{-1}$ & $\begin{array}{c}0.45 \mathrm{~L} .200 \\
\mathrm{~L} \mathrm{H}_{2} \mathrm{O}^{-1}\end{array}$ \\
\hline & $\begin{array}{l}\text { Glyphosate- } \\
\text { isopropylamine } \\
\text { salt }\end{array}$ & Trop SL ${ }^{\circledR}$ & Substituted glycine & $480 \mathrm{~g} \mathrm{~L}^{-1}$ & $\begin{array}{c}2 \mathrm{~L} .200 \mathrm{~L} \\
\mathrm{H}_{2} \mathrm{O}^{-1}\end{array}$ \\
\hline
\end{tabular}


contuation...

\begin{tabular}{|c|c|c|c|c|c|}
\hline \multirow{4}{*}{ Fungicide } & $\begin{array}{l}\text { Azoxystrobin + } \\
\text { benzovindiflupyr }\end{array}$ & Elatus WG ${ }^{\circledR}$ & $\begin{array}{l}\text { Strobilurin }+ \\
\text { pyrazolcarboxamide }\end{array}$ & $\begin{array}{r}300 \mathrm{~g} \mathrm{~kg}^{-1}+ \\
150 \mathrm{~g} \mathrm{~kg}^{-1}\end{array}$ & $\begin{array}{c}300 \text { g. } 200 \\
\mathrm{~L} \mathrm{H}_{2} \mathrm{O}^{-1}\end{array}$ \\
\hline & $\begin{array}{l}\text { Azoxystrobin + } \\
\text { cyproconazole }\end{array}$ & Priori Xtra SC ${ }^{\circledR}$ & Strobilurin + triazole & $\begin{array}{l}200 \mathrm{~g} \mathrm{~L}^{-1}+ \\
80 \mathrm{~g} \mathrm{~L}^{-1}\end{array}$ & $\begin{array}{c}0.3 \mathrm{~L} .200 \\
\mathrm{~L} \mathrm{H}_{2} \mathrm{O}^{-1}\end{array}$ \\
\hline & $\begin{array}{c}\text { Cyproconazole + } \\
\text { trifloxystrobin }\end{array}$ & $\begin{array}{l}\text { Sphere Max } \\
\text { SC }^{\circledR}\end{array}$ & Strobilurin + triazole & $\begin{array}{c}160 \mathrm{~g} \mathrm{~L}^{-1}+ \\
375 \mathrm{~g} \mathrm{~L}^{-1}\end{array}$ & $\begin{array}{l}0.2 \mathrm{~L} .200 \\
\mathrm{~L} \mathrm{H}_{2} \mathrm{O}^{-1}\end{array}$ \\
\hline & $\begin{array}{l}\text { Metconazole + } \\
\text { pyraclostrobin }\end{array}$ & $\begin{array}{c}\text { Opera Ultra } \\
\text { EC }^{\oplus}\end{array}$ & Strobilurin + triazole & $\begin{array}{l}80 \mathrm{~g} \mathrm{~L}^{-1}+ \\
130 \mathrm{~g} \mathrm{~L}^{-1}\end{array}$ & $\begin{array}{l}0.6 \mathrm{~L} .200 \\
\mathrm{~L} \mathrm{H}_{2} \mathrm{O}^{-1}\end{array}$ \\
\hline
\end{tabular}

\section{Statistical analysis}

The data obtained in the bioassays were analyzed for normality (Shapiro \& Wilk, 1965) and homogeneity of variance for each treatment (Burr \& Foster, 1972), and if necessary, were transformed to perform ANOVA. The treatment means were then compared using Tukey's test at the 5\% probability level (Statistical Analysis System Institute [SAS Institute], 2001).

\section{Results and Discussion}

Caterpillars of $C$. includens that fed on treated diets with herbicides or fungicides without association with ChinNPV (Bioassay
1) had similar mortality (\%) as control (sterile distilled water) (5.65\%), except when the diet was treated with the herbicide Soyvance Pre, which resulted in higher caterpillar mortality (30.29\%). This value was lower than the mortality recorded for ChinNPV (81.35\%) (Table 2).

When the diets were treated with herbicides or fungicides mixed with ChinNPV (bioassay 2), the mortality of caterpillars was equivalent to the isolated use of ChinNPV (86.80\%), with values varying from $79.67 \%$ (Flumyzin 500 ) to $90.98 \%$ mortality [imazapique + imazapir (Soyvance Pre)]. Lower C. includens mortality (\%) was observed in the control (6.67\%) (Table 2). 
Table 2

Mortality of Chysodeixis includens (\%) due to the ingestion of different pesticides alone (bioassay 1) or in a mixture with ChinNPV offered at different times of mixing (bioassays 2,3 , and 4)

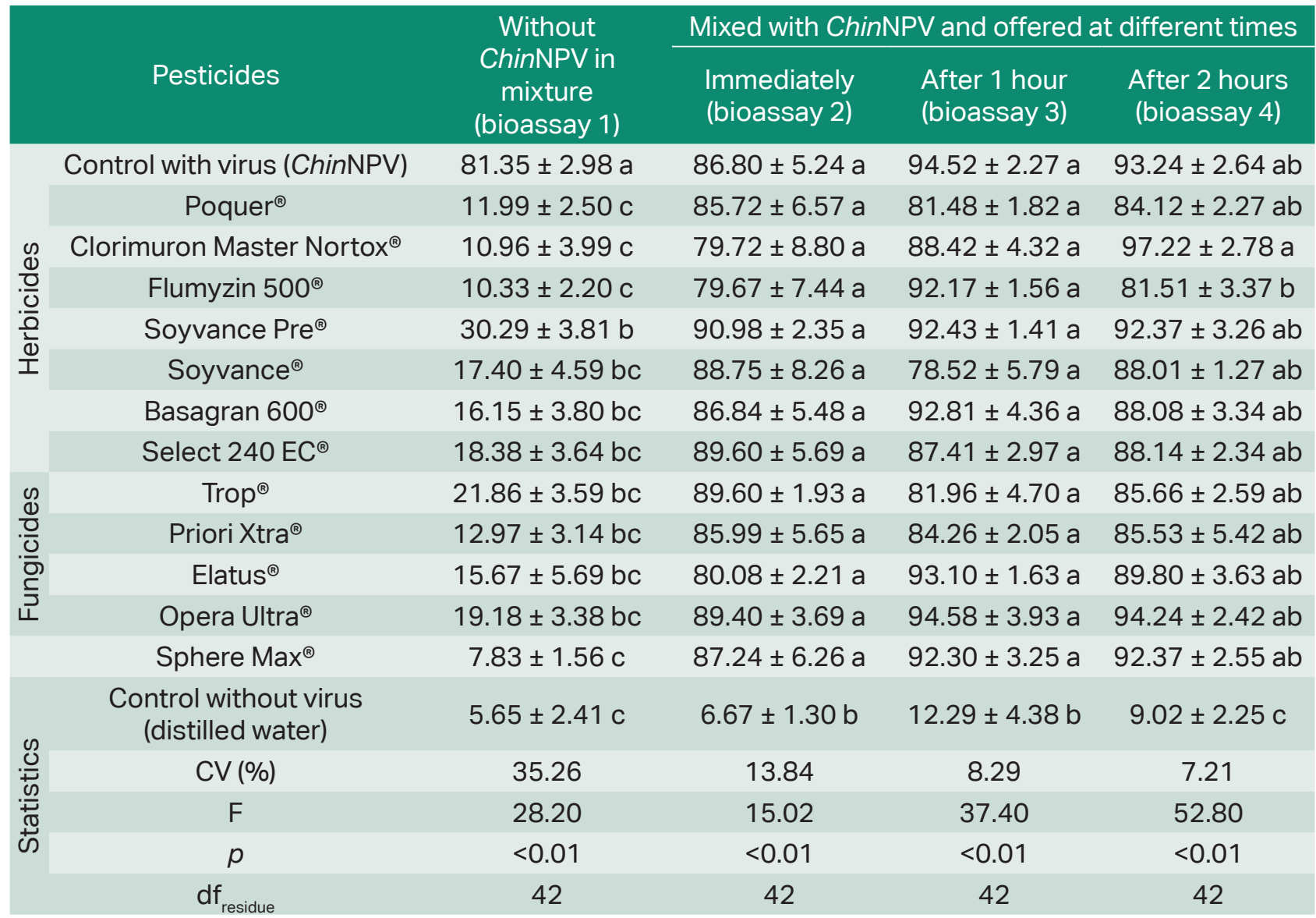

Means \pm EPM followed by the same letter in each column do not differ based on Tukey's test (5\% probability).

Regarding the mixture compatibility of ChinNPV with herbicides and fungicides for one $\mathrm{h}$ (bioassay 3) after mixing, both herbicides and fungicides did not reduce $\mathrm{C}$. includens mortality (\%) compared with the mortality using baculovirus alone (94.52\%), ranging from $78.52 \%$ (Soyvance) to $94.58 \%$ mortality (Opera Ultra). These values were all higher than C. includens mortality (\%) recorded in the control (sterile distilled water) (12.29\%) (Table 2).
Similarly, in the evaluation of C. includens mortality (\%) triggered by ChinNPV after mixing with herbicides or fungicides for two h (bioassay 4), all mixed treatments triggered caterpillar mortality (\%) significantly higher than that of the control (9.02\%). Although ChinNPV mixed with Flumyzin 500 had lower mortality (81.51\%) than ChinNPV mixed with Clorimuron Master Nortox (97.22\%), both had similar mortality to that by using ChinNPV alone (93.24\%), and all of them triggered C. includens mortality higher than $80 \%$ (Table 2), 
which is considered acceptable for integrated pest management.

In the present study, it was proved that some of the most commonly used fungicides and herbicides in soybean crops can be used in a mixture with ChinNPV in a tank without reducing its pathogenicity to $\mathrm{C}$. includens compared to the isolated spray of baculovirus. In soybean, a similar combination of tools to manage different pests has been previously reported in the literature with the simultaneous use of the herbicide Roundup Ready ${ }^{\circledR}$ and the parasitoid Palmistichus elaeisis Delvare \& LaSalle, 1993 (Hymenoptera: Eulophidae), which controls Anticarsia gemmatalis Hubner, 1818 (Lepidoptera: Erebidae) (De La Cruz et al., 2017). The active ingredients of the fungicides myclobutanil, potassium bicarbonate, and cyprodinil + fludioxonill has been shown to be safe for Orius insidiosus Say, 1832 (Hemiptera: Anthocoridae), which is a generalist predator present in different major crops (Gradish, Scott-Dupree, Shipp, Harris, \& Ferguson, 2011). In contrast, the mixture of herbicides with active ingredients oxyfluorfen, glufosinateammonium, metribuzin, and linuron, was not compatible with entomopathogenic nematodes belonging to the genera Steinernema and Heterorhabditis (Laznik \& Trdan, 2017), demonstrating the importance of studying different combinations in order to offer growers the most precise information about what could and could not be done. These different outcomes, depending upon the studied combination with fungicides, have also been reported earlier. The entomopathogenic fungi Beauveria bassiana and Metarhizium anisopliae are not compatible with fungicides with the active ingredients azoxystrobin, chlorothalonil, and thi-ophanate-methyl, causing a decrease in the growth of the fungi (Fiedler \& Sosnowska, 2017).
The compatibility of ChinNPV with herbicides and fungicides was shown in this study. We demonstrated yet another important factor. The effectiveness of the baculovirus in tank mixing conditions during the application period, even after two $h$ of the mixing, was maintained the same with caterpillar mortality close to or higher than $80 \%$. This is similar to the mortality triggered by different baculoviruses. The use of ChinNPV alone caused mortality rates greater than $95 \%$ for the soybean looper (Morgado et al., 2020; Muraro et al., 2018). This indicates that it is possible to use ChinNPV in a mixture in the application of herbicides and fungicides when necessary, without compromising the control of $\mathrm{C}$. includens. The use of viruses to control soybean looper, in addition to achieving success in controlling the target insect, can be a resistance management tool (Godoy et al., 2019). The compatibility and pathogenicity studies of any biological control agent are very important; however, guaranteeing the stability of the control agent by simulating the conditions found at the time of application generates practical knowledge to strongly support their recommendation in the field.

\section{Conclusion}

In the present study, simulating the mixing conditions inside the application tank and the average application time in the field, demonstrated that these factors did not interfere with the pathogenicity of ChinNPV. These factors also demonstrate that ChinNPV, in addition to being compatible with different studied pesticides, has the necessary stability to maintain effectiveness under conditions of application in the field. 


\section{References}

Andrade, K., Bueno, A. de F., Silva, D. M., Stecca, C., Pasini, A., \& Oliveira, M. C. N. (2016). Bioecological characteristics of Chrysodeixis includens (Lepidoptera: Noctuidae) fed on different hosts. Austral Entomology, 55(4), 449-454. doi: 10.1111/ aen.12208

Bortolotto, O. C., Pomari-Fernandes, A., Bueno, R. C. O. de F., Bueno, A. de F., Cruz, Y. K. S. da, Sanzovo, A., \& Ferreira, R. B. (2015). The use of soybean integrated pest management in Brazil: a review. Agronomy Science and Biotechnology, 1(1), 25. doi: 10.33158/asb.2015v1i1p25

Bueno, R., Raetano, C. G., Dorneles, J. Jr., \& Carvalho, F. K. (2017). Integrated Management of Soybeans Pests: The Example of Brazil. Outlooks on Pest Anagement, 28(4), 1-4. doi: 10.1564/v28

Burr, I. W., \& Foster, L. A. (1972). A test for equality of variances (Mimeo Series, $n$. 282). West Lafayette: University of Purdue.

De La Cruz, R. A., Zanuncio, J. C., Lacerda, M. C., Wilcken, C. F., Fernandes, F. L., Tavares, W. D. S.,... Sediyama, C. S. (2017). Sideeffects of pesticides on the generalist endoparasitoid Palmistichus elaeisis (Hymenoptera: Eulophidae). Scientific Reports, 7(1), 1-8. doi: 10.1038/s41598017-10462-3

Fiedler, Z., \& Sosnowska, D. (2017). Side effects of fungicides and insecticides on entomopathogenic fungi in vitro. Journal of Plant Protection Research, 57(4), 355360. doi: 10.1515/jppr-2017-0048

Godoy, D. N., Führ, F. M., Stacke, R. F., Muraro, D. S., Marçon, P., Popham, H. J. R., \& Bernardi,
O. (2019). No cross-resistance between ChinNPV and chemical insecticides in Chrysodeixis includens (Lepidoptera: Noctuidae). Journal of Invertebrate Pathology, 164(6), 66-68. doi: 10.1016/j. jip.2019.05. 001

Gradish, A. E., Scott-Dupree, C. D., Shipp, L., Harris, C. R., \& Ferguson, G. (2011). Effect of reduced risk pesticides on greenhouse vegetable arthropod biological control agents. Pest Management Science, 67(1), 82-86. doi: 10.1002/ps.2036

Greene, G. L., Leppla, N. C., \& Dickerson, W. A. (1976). Velvetbean caterpillar: a rearing procedure and artificial medium. Journal of Economic Entomology, 69(4), 487-488. doi: 10.1093/jee/69.4.487

Hartman, G. L., West, E. D., \& Herman, T. K. (2011). Crops that feed the World 2. Soybean-worldwide production, use, and constraints caused by pathogens and pests. Food Security, 3(1), 5-17. doi: 10.1007/s12571-010-0108-x

Laznik, Ž., \& Trdan, S. (2017). The influence of herbicides on the viability of entomopathogenic nematodes (Rhabditida: Steinernematidae and Heterorhabditidae). International Journal of Pest Management, 63(2), 105-111. doi: 10.1080/09670874.2016.1227882

Morgado, F. da S., Silva, L. A., Bernardes, L. M., Czepak, C., Strand, M. R., \& Ribeiro, B. M. (2020). Trichoplusia ni and Chrysodeixis includens larvae show different susceptibility to Chrysodeixis includens single nucleopolyhedrovirus per os infection. Journal of Pest Science, 93(3), 1019-1029. doi: 10.1007/s10340-020-01 217-7 
Moscardi, F. (1999). Assessment of the application of baculoviruses for control of Lepidoptera. Annual Review of Entomology, 44(1), 257-289. doi: 10.1146/ annurev.ento.44.1.257

Muraro, D. S., Giacomelli, T., Stacke, R. F., Godoy, D. N., Marçon, P., Popham, H. J. R., \& Bernardi, O. (2018). Baseline susceptibility of brazilian populations of Chrysodeixis includens (Lepidoptera: Noctuidae) to C. includens nucleopolyhedrovirus and diagnostic concentration for resistance monitoring. Journal of Economic Entomology, 112(1), 349-354. doi: 10.10 93/jee/toy361

Oerke, E. C. (2006). Crop losses to pests. Journal of AgriculturalScience, 144(1), 3143. doi: $10.1017 / S 0021859605005708$

Pignati, W. A., Lima, F. A. N. de S. e, Lara, S. S. de, Correa, M. L. M., Barbosa, J. R., Leão, L. H. D. C., \& Pignatti, M. G. (2017). Distribuição espacial do uso de agrotóxicos no Brasil: uma ferramenta para a vigilância em saúde. Ciencia e Saude Coletiva, 22(10), 3281-3293. doi: 10.1590/1413812320172210.17742017
Statistical Analysis System Institute (2001). SAS user's guide: statistics (Version 8.2, 6nd ed.). Cary: SAS Institute.

Shapiro, S. S., \& Wilk, M. B. (1965). An analysis of variance test for normality. Biometrika, 52(3/4), 591-611. doi: 10.2307/2333709

Stacke, R. F., Godoy, D. N., Halberstadt, S. A., Bronzatto, E. S., Giacomelli, T., Hettwer, B. L, Muraro, D. S., Guedes, J. VC \& Bernardi, O. (2020). Inheritance of lambdacyhalothrin resistance, fitness costs and cross-resistance to other pyrethroids in soybean looper, Chrysodeixis includens (Lepidoptera: Noctuidae). Crop Protection, 131(5), 105096. doi: 10.1016/j. cropro.2020.10509

Zulin, D., Ávila, C., \& Schlick-Souza, E. C. (2018). Population fluctuation and vertical distribution of the soybean looper (Chrysodeixis includens) in soybean culture. American Journal of Plant Sciences 9(7), 1544-1556. doi: 10.4236/ ajps.2018.97113 
